\title{
KETERLIBATAN KELUARGA SEBAGAI PENDAMPING PASIEN DEMI MECEGAH BAHAYA DAN ADVERSE EVENTS DI PELAYANAN KESEHATAN
}

Fitri Rahman Batubara

$\underline{\text { Fitri.batubara.fr@gmail.com }}$

\begin{abstract}
Abstrak
Proses penyembuhan bagi pasien di pelayanan kesehatan tidak terlepas dari peran keluarga. Keluarga merupakan bagian yang penting dalam proses penyembuhan bagi pasien. Dukungan keluaga sangat diperlukan untuk memotivasi selama pengobatan dan peawatan di pelayanan kesehatan.Hampir setiap tindakan medis menyimpan potensi resiko. Banyaknya jenis obat, jenis pemeriksaan dan prosedur, serta jumlah pasien dan staf Rumah Sakit yang cukup besar,merupakan hal yang potensial bagi terjadinya kesalahan medis (medical errors). Menurut Institute of Medicine (1999), kesalahan medis didefinisikan sebagai: suatu Kegagalan tindakan medis yang telah direncanakan untuk diselesaikan tidak seperti yang diharapkanatau perencanaan yang salah untuk mencapai suatu tujuan yaitu kesalahan perencanaan. Kesalahan yang terjadi dalam proses asuhan medis ini akan mengakibatkan atau berpotensi mengakibatkan cedera pada pasien, bisa berupa Near Miss atau Adverse Event (KejadianTidak Diharapkan/KTD)
\end{abstract}

Kata Kunci : Peran Keluarga, Mencegah bahaya dan adverse events 
1. Latar Belakang

Keselamatan pasien rumah sakit adalah suatu sistem yang diterapkan untuk mencegah terjadinya cedera akibat perawatan medis dan kesalahan pengobatan melalui suatu sistem assesment resiko, identifikasi dan pengelolaan faktor risiko, pelaporan dan analisis insiden, kemampuan belajar dan tindak lanjut dari insident serta implementasi solusi untuk meminimalkan timbulnya risiko. Keselamatan pasien merupakan suatu sistem untuk mencegah terjadinya cedera yang disebabkan oleh kesalahan akibat melaksanakan suatu tindakan atau tidak mengambil tindakan yang seharusnya diambil. Near Miss atau Nyaris Cedera (NC) merupakan suatu kejadian akibat melaksanakan suatutindakan (commission) atau tidak mengambil tindakan yang seharusnya diambil (omission),yang dapat mencederai pasien, tetapi cedera serius tidak terjadi, karena keberuntungan(misalnya,pasien terima suatu obat kontra indikasi tetapi tidak timbul reaksi obat), pencegahan (suatu obat dengan overdosis lethal akan diberikan, tetapi staf lain mengetahuidan membatalkannya sebelum obat diberikan), dan peringanan (suatu obat dengan overdosislethal diberikan, diketahui secara dini lalu diberikan antidotenya Adverse Event atau Kejadian Tidak Diharapkan (KTD) merupakan suatu kejadian yang mengakibatkan cedera yang tidak diharapkan pada pasien karena suatu tindakan (commission) atau tidak mengambil tindakan yang sebenarnya diambil (omission) dan bukan karena "underlying disease" atau kondisi pasien. Peran keluarga sesuai dengan tugas-tugas keluarga dalam bidang kesehatan salah satunya adalah memberikan perawatan kepada anggota keluarga yang sakit dan yang tidak dapat membantu dirinya sendiri karena cacat atau usia terlalu muda. Peran keluarga tersebut meliputi mengingatkan/memonitor waktu minum obat, mengontrol persediaan obat, mengantarkan penderita kontrol, memisahkan alat-alat penderita dengan anggota keluarga lain, meningkatkan kesehatan lingkungan penderita, dan pemenuhan kebutuhan psikologis agar penderita tidak merasa terisolir dalam 
lingkungannya Dalam

melaksanakan program tersebut diperlukan kerja sama antara tim kesehatan serta pasien dan keluarga.

Keluarga merupakan unit paling dekat dengan pasien, dan merupakan perawat utama bagi pasien. Keluarga berperan dalam menentukan cara atau perawatan yang diperlukan pasien di rumah sakit. Keberhasilan perawat di rumah sakit akan sia-sia jika tidak diteruskan di rumah yang kemudian mengakibatkan pasien harus dirawat kembali (kambuh). Peran serta keluarga sejak awal perawatan di rumah sakit akan meningkatkan kemampuan keluarga merawat pasien di rumah sehingga memungkinkan pasien tidak kambuh atau dapat dicegah. pasien dan keluarga pasien yang dilibatkan dalam pengambilan keputusan secara bersama-sama dalam perawatan dan menjadikan pasien sebagai mitra dapat meningkatkan optimalisasi kesembuhan pasien.

\section{Metode}

Kajian ini menggunakan metode kualitatif, metode ini bersifat memberikan penjelasan dengan membuat analisis. Proses pengkajian ini lebih menggunakan landasan teori dengan mengumpulkan data, bereksplorasi bebas yang telah disimpulkan dari berbagai sumber-sumber, yaitu buku, majalah, koran, jurnal print maupun jurnal online bertema perencanaan keperawatan. Saya membaca dari berbagai referensi berupa buku, jurnal print maupun jurnal online. Melalui metode ini saya memahami dan mengidentikasi perencanaan keperawatan, bagaimana membuat prioritas masalah, membuat tujuan dan kriteria hasil, memutuskan perencanan keperawatan yang akan diimplementasikan. Metode ini juga berusaha menjelaskan, mengumpulkan, dan menginterpretasikan data yang dilanjutkan dengan faktor-faktor yang berhubungan dengan situasi dan kondisi yang terjadi.

\section{Hasil}

Peran serta keluarga sejak awal perawatan di rumah sakit akan meningkatkan kemampuan keluarga merawat pasien di rumah sehingga memungkinkan pasien tidak kambuh 
atau dapat dicegah karena keluarga merupakan unit paling dekat dengan pasien, dan merupakan perawat utama bagi pasien. Keluarga berperan dalam menentukan cara atau perawatan yang diperlukan pasien di rumah sakit. Untuk itu dibutuhkan juga pengetahuan keluarga untuk menghindari kejadian tidak diharapkan (KTD). Kejadian tidak diharapkan (KTD)/ adverse event yaitu insiden yang mengakibatkan cedera pada pasien akibat melaksanakan suatu tindakan atau tidak mengambil tindakan yang seharusnya diambil, dan bukan karena penyakit dasarnya atau kondisi pasien. Cedera dapat diakibatkan oleh kesalahan medis atau bukan kesalahan medis. Tujuan bertujuan untuk:

1. Terciptanya budaya keselamatan pasien dirumah sakit

2. Meningkatnya akuntabilitas rumah sakit terhadap pasien dan masyarakat.

3. Menurunnya Kejadian Tak Diharapkan (KTD)

4. Terlaksananya program pencegahan sehingga tidak terjadi pengulangan KTD
Dengan terlibatnya keluarga pasien dapat meningkatkan tingkat keselamatan pasien pada saat berada di unit pelayanan kesehatan. Pasien dan keluarganya mempunyai hak untuk mendapatkan informasi tentang rencana dan hasil pelayanan termasuk kemungkinan terjadinya KTD. Keselamatan dalam pemberian pelayanan dapat ditingkatkan dengan keterlibatan pasien dan keluarga dalam proses pelayanan. Karena itu, di RS harus ada system dan mekanisme mendidik pasien \& keluarganya tentang kewajiban \& tanggung jawab pasien dalam asuhan pasien. Karena itu selama di rumah sakit keluarga berhak atas informasi pengobatan, perawatan, dan penanganan lainnya terhadap penderita.

\section{Pembahasan}

Adverse Event adalah suatu peristiwa yang menyebabkan, atau memiliki potensi yang dapat menyebabkan, atau menyebabkan hal yang terduga atau tidak diinginkan sehingga membahayakan keselamatan pengguna alat kesehatan (termasuk pasien) atau orang lain. (Reporting Adverse Incidents and Disseminating Medical Device Alerts, MHRA). Kejadian tak terduga atau tidak diinginkan sebagai akibat negatif dari 
manajemen di bidang kesehatan, tidak terkait dengan perkembangan alamiah penyakit atau komplikasi penyakit yang mungkin terjadi (London Health Sciences Centre). Kesalahan yang mengakibatkan IKP dapat terjadi pada :

1.Diagnostik : kesalahan atauketerlambatan diagnosis

2.Treatment : kesalahan pada operasi, proseduratautes, pelaksanaan

3. Preventive : tidak memberikan terap iprofilaktif, monitoring atau follow

4. Up : yang tidaksesuaipadasuatupengobatan

5. Other : gagal melakukan komunikasi, gagal alat atau sistem lain

Insiden Advers Events diklasifikasi sebagai berikut :

- Mengakibatkan kematian atau cedera yang serius.disebut Kejadian Sentinel Kejadian Sentinel Kejadian Sentinel (Sentinel Event) : Suatu KTD yang mengakibatkan kematian atau cedera yang serius; biasanya dipakai untuk kejadian yang sangat tidak diharapkan atau tidak dapat diterima seperti : operasi pada bagian tubuh yang salah. Pemilihan kata "sentinel" terkait dengan keseriusan cedera yang terjadi (mis. Amputasi pada kaki yg salah, dsb) sehingga pecarian fakta terhadap kejadian ini mengungkapkan adanya masalah yang serius pada kebijakan \& prosedur yang berlaku.

- selanjutnya KNC (Kejadian Nyaris Cedera) adalah Kejadian yang berpotensi menyebabkan kerugian atau bahaya, akan tetapi karena faktor keberuntungan hal tersebut tidak terjadi Kejadian Nyaris Cedera (KNC) meliputi keadaan sebagai berikut

a). Kejadian yang berpotensi menyebabkan cidera yang berkaitan dengan pelayanankepada pasien tetapi dapat dihindari / dicegah dan perlu dilaporkan kepada timkeselamatan pasien RS.

b). Kejadian yang berpotensi menyebabkan kerugian / bahaya yang tidak berkaitan langsungdengan pelayanan kepada pasien tetapi dapat dihindari / dicegah dan tidak perludilaporkan kepada tim keselamatan pasien RS tetapi dapat 
diselesaikan oleh unit
terkaitantara lain :
•Kejadian yang
berkaitan dengan
administrasi keuangan

Kejadian

kehilangan barang milik pasien / keluarga pasien

- Kejadian komplain pasien / keluarga pasien sudah terpapar ke pasien, tetapi tidak timbul cedera disebut. Kejadian Tidak Cedera, selanjutnya disingkat KTC Kejadian Tidak Cedera adalah insiden yang sudah terpapar ke pasien, tetapi tidak menimbulkan cedera, dapat terjadi karena

"keberuntungan"
(misal; pasien
terima suatu obat
kontra indikasi
tetapi tidak timbul
reaksi obat), atau
"peringanan" (suatu
obat dengan reaksi
alergi diberikan,

diketahui secara dini lalu diberikan antidotumnya).

- Berpotensi untuk menimbulkan cedera, tetapi belum terjadi insiden disebut Kondisi Potensial Cedera (KPC).

Tindakan keperawatan yang diberikan kepada pasien sudah seharusnya menunjang keselamatan pada pasien karena proses keperawatan tersebut sangat berhubungan denganpatient safety atau keselamatan pasien. Proses keperawatan tersebut meliputi proses pengkajian, diagnosa, perencanaan, implementasi, dan evaluasi. Jika terjadi kesalahan saat menjalani salah satu proses keperawatan, maka kesalahan tersebut akan memungkinkan timbulnya kecelakaan kerja yang dapat mengancam keselamatan pasien. Aplikasi keselamatan pasien dapat diterapkan pada beberapa tempat yang terdapat di rumah sakit, seperti kamar operasi, ICU, dan UGD. Aplikasi keselamatan pasien tersebut diterapkan dengan memperhatikan sisi struktur, lingkungan, peralatan dan teknologi, proses, orang, dan budaya. Program Keselamatan rumah sakit dan keselamatan pasien merupakan suatu kebutuhan dan keharusan untuk 
melindungi pasien dan karyawan. Keterlibatan /pemberdayaan pasien dalam proses asuhan pelayanan kesehatan harus menjadi prioritas utama. Keterlibatan seluruh unsur yang ada dalam organisasi merupakan kunci keberhasilan, termasuk pihak manajemen, unit terkait serta mengoptimalkan peran champion. Sosialisasi Program keselamatan rumah sakit dan keselamatan pasien harus dilakukan secara terus-menerus untuk menjaga pelaksanaan program tetap konsisten dan berkesinambungan. Peran keluarga sesuai dengan tugastugas keluarga dalam bidang kesehatan salah satunya adalah memberikan perawatan kepada anggota keluarga yang sakit dan yang tidak dapat membantu dirinya sendiri karena cacat atau usia terlalu muda. Peran keluarga tersebut meliputi mengingatkan/memonitor waktu minum obat, mengontrol persediaan obat, mengantarkan penderita kontrol, memisahkan alat-alat penderita dengan anggota keluarga lain, meningkatkan kesehatan lingkungan penderita, dan pemenuhan kebutuhan psikologis agar penderita tidak merasa terisolir dalam lingkungannya. selain itu dengan melibatkan anggota keluarga seperti berpartisipasi dalam koordinasi keperawatan sangat penting. Keluarga merupakan bagian dari tim pengobatan dan perawatan. Apalagi di Indonesia dengan kultur sosialnya tinggi ditambah keterbatasan jumlah perawat di rumah sakit sehingga tugas merawat orang sakit yang dirawat di rumah sakit umumnya dilakukan oleh keluarga yang menjaga. Para anggota keluarga menunggui secara bergantian, bahkan sering menjaga bersama-sama. Sementara perawat di rumah sakit yang seharusnya merawat orang sakit juga harus melakukan tugas-tugas yang lain di bangsal perawatan. Maka, peran keluarga penting untuk memantau kebutuhan pasien dari laporan perawat atau jika perlu melakukan komunikasi langsung. Beberapa rumah sakit mengizinkan pasien untuk membawa alat komunikasi yang perlu digunakan. Hal ini juga terbukti dari hasil penelitian yang dilakukan di rumah sakit Amerika serikat bahwa dengan keterlibatan pasien maupun anggota keluarganya dalam merawat dan memberikan kesempatan kepada keluarga pasien untuk berkunjung ke rumah sakit lebih lama dapat menguragi resiko kecemasan yang berlebihan yang diderita oleh pasien. Tentunya hal ini dapat dirasakan jika penderita merasakan adanya dukungan sosial dari orang-orang sekitarnya, merasa dirinya dihargai, diperhatikan 
dan dicintai. Contohnya adalah bila ada seseorang yang sakit dan terpaksa di rawat di rumah sakiy maka sanak saudara ataupun teman-teman biasanya datang berkunjung. Dengan kunjungan tersebut maka orang yang sakit atau pasien ini tentu merasa mendapat dukungan sosial sehingga secara tidak langsung dapat mempercepat kesembuhan. Keluarga yang akan menerima penderita di rumah sepulang dari rumah sakit. Begitu siap dipulangkan keluarga menerima estafet pengelolaan penderita di rumah sebagai kelanjutan pengelolaan di rumah sakit. Karena itu selama di rumah sakit keluarga berhak atas informasi pengobatan, perawatan, dan penanganan lainnya terhadap penderita. Karena itu bertanya kepada pihak rumah sakit merupakan hak keluarga untuk memperoleh informasi tersebut. Keluarga perlu perlu mulai membuka dan menjalin 'kedekatan' dengan personel rumah sakit untuk keperluan ini.

\section{Penutup}

Peran keluarga memiliki peran penting sebagai pendamping dan pemberi motivasi untuk pasien dalam pelayanan kesehatan. Keterlibatan keluaga juga berpengaruh dalam pencegahan bahaya dan adverse event. Keselamatan pasien adalah proses dalam suatu rumah sakit yang memberikan pelayanan pasien secara aman. Proses tersebut meliputi pengkajian mengenai resiko, identifikasi, manajemen resiko terhadap pasien, pelaporan dan analisis insiden, kemampuan untuk belajar dan menindaklanjuti insiden, dan menerapkan solusi untuk mengurangi serta meminimalisir timbulnya risiko. Pelayanan kesehatan yang diberikan tenaga medis kepada pasien mengacu kepada tujuh standar pelayanan pasien rumah sakit yang meliputi hak pasien, mendididik pasien dan keluarga, keselamatan pasien dan kesinambungan pelayanan, penggunaan metode- metode peningkatan kinerja untuk melakukan evaluasi dan program peningkatan keselamatan pasien. 


\section{Referensi}

Andini A., Kamsih A., Siti N. F. L.

2016. EFEKTIVITAS MULTIPLE

FAMILY THERAPY UNTUK

PENURUNAN BEBAN

PENDAMPING ORANG

DENGAN SKIZOFRENIA.

Jurnal Insight, 1 (1).

Angelita L., Julita R., Michael K.

2016. HUBUNGAN PERILAKU

DENGAN KEMAMPUAN

PERAWAT DALAM

MELAKSANAKAN

KESELAMATAN PASIEN

(PATIENT SAFETY) DI RUANG

AKUT INSTALASI GAWAT

DARURAT RSUP PROF. DR. R.

D. KANDOU MANADO. $E$ -

Journal Keperawatan (e-kp), 4 (2).

Colti S., Bambang H., Munasib, Septi M. S. 2018. PERAN KELUARGA DDAAM PENCEGAHAN HIV/AIDS DI KECAMATAN PURWOKRTO SELATAN. Jurnal ilm. Kel. \& Kons., 11 (2).

Hajjul Kamil. 2017. PATIENT SAFETY. Idea Nursing Journal. 1 (1).
Jufrizal. 2016. Peran Keluarga Sebagai Pengawas Menelan Obat (PMO) Dengan Tingkat Keberhasilan Pengobatan Tuberkulosis Paru. Jurnal Ilmu Keperawatan, 4(1).

Kadek Y. E., Yohannes K. H. 2018. Dukungan Sosial Keluarga Terhadap Pemulihan Orang dengan Skizofrenia (ODS) di Bali. Jurnal Psikologi Udayana, 5 (2).

Karina D. K., Aries W. 2012. PERAN PENDAMPINGAN SPIRITUAL TERHADAP MOTIVASI KESEMBUHAN PADA PASIEN LANJUT USIA. Jurnal STIKES, 5 (1).

Liza $\quad 2020$. PENERAPAN KESELAMATAN PASIEN RUMAH SAKIT. Jurnal Averrous, 6(1).

Nahdah S. Z., Linglling M. P. 2020. PERAN KELUARGA SEBAGAI PENGAWAS MENELAN OBAT ANTI TUBERKULOSIS PADA PASIEN TB PARU KAMBUH. Jurnal Media Keperawatan : Politeknik Kesehatan Makassar, 11(1). 
Simamora, R. H. (2019). Buku ajar pelaksanaan identifikasi

pasien. Uwais Inspirasi Indonesia.

Yetik M., Muhammad A. 2017.

PERILAKU PENCEGAHAN

PENULARAN HIV / AIDS.

Jounal Of Health Education, 2 (2). 